\title{
Yunia dichotoma, a Lower Devonian plant from Yunnan, China
}

\author{
Hao Shou-Gang and Charles B. Beck ${ }^{\mathrm{b}}$ \\ ${ }^{a}$ Department of Geology, Peking University, Beijing 100871, China \\ ${ }^{\mathrm{b}}$ Museum of Paleontology and Department of Biology, University of Michigan, Ann Arbor 48109, MI, U.S.A.
}

(Received August 20, 1990; revised and accepted December 6, 1990)

\begin{abstract}
Hao, S.-G. and Beck, C.B., 1991. Yunia dichotoma, a Lower Devonian plant from Yunnan, China. Rev. Palaeobot. Palynol., 68 : $181-195$.

This paper describes a new genus and species, Yunia dichotoma, collected from the Posonchong Formation of Siegenian age in the Wenshan district of Yunnan, China. The spiny axes are characterized by cruciate dichotomy. Associated, but not in organic connection, with the vegetative axes, are numerous elongate-elliptical or ovoid sporangia. One small branching system consisting of a single dichotomy bears the basal part of a sporangium, suggesting the possibility that the sporangia were borne terminally in pairs. Sections of permineralized segments of the axis reveal a columnar protostele, circular to elliptical in transverse section containing one or two roughly circular to transversely elongate (often lunate) regions of large parenchyma cells sparsely interspersed peripherally with tracheids of small diameter. We interpret these regions of parenchyma and tracheids to be protoxylem strands and development of primary xylem to be centrarch. During branching of an axis, the initially single protoxylem region in a branch stele divides precociously prior to the separation of the daughter axes. Thus, the stele may contain two protoxylem strands through considerable lengths of daughter axes between levels of dichotomy. Yunia is tentatively assigned to the Trimerophytales.
\end{abstract}

\section{Introduction}

It has been 142 years since J.W. Dawson established the genus, Psilophyton. The discovery of the Rhynie plants in the mid 1920's stimulated great interest in, and resulted in increased research activity on, early Devonian plants for several decades. More recently, the recognition by $\mathrm{H}$. P. Banks $(1968,1975)$ of three major groups of primitive vascular plants, the rhyniophytes, zosterophyllophytes and trimerophytes, has resulted, during the last three decades, in a renewal of interest in the first land plants and the development of a wealth of new anatomical and morphological information.

Anatomically, most vascular plants of Lower Devonian age are characterized by a solid circular or elliptical stelar column with primary xylem development centrarch (rhyniophytes, trimero- phytes) or exarch (zosterophyllophytes and lycophytes). Additional anatomical diversity is reflected, for example, in the stellate xylem column of Baragwanathia (see: Grierson and Banks, 1963) and the deeply three-ribbed stele of a plant described by Gensel (1984) from the upper Lower Devonian of Gaspe, Canada. The plant described in this paper exhibits still further anatomical diversity. Perhaps this is not surprising since several plants from the Lower Devonian, Posonchong formation of Yunnan have been discovered recently that demonstrate remarkable diversity in external morphology morphologies quite different from those commonly attributed to early vascular plants that lived on other equatorial continental plates during the early Devonian [see: e.g., Stachyophyton, Huia (Geng, 1983, 1985), Eophyllophyton (Hao, 1988), Discalis (Hao, 1989a), Gumuia (Hao, 1989b) and Catenalis (Hao and Beck, in press)]. 
The main accumulation of knowledge about early vascular plants has been derived from fossils of plants that comprised the flora of Laurussia (that today includes central and northern Europe, Greenland and North America) during the early Devonian. Whereas eastern Yunnan, a part of the South China Block, was probably a part of Gondwana during the early Paleozoic (see: Fang, 1989), Fang and Van der Voo (1989) conclude that by Devonian times it occupied an equatorial position. Consequently, these plants probably evolved under conditions of temperature and photoperiod very similar to those experienced by vascular plants evolving concurrently in Laurussia. And yet, they differed from these latter plants in some rather striking ways as, for example, the unusual histology of the haplostele of Yunia, the laminate appendages of Eophyllophyton (Hao, 1988) and the alga-like morphology of Catenalis (Hao and Beck, in press). One is, therefore, stimulated to ask why the plants of the Posonchong flora are so different from those represented by fossils collected from early Devonian sediments in central and northern Europe and North America. The long isolation during and prior to the early Devonian of the China plate (Bambach et al., 1980) may provide part of the reason for the evolution of numerous endemics. Perhaps because of a major ocean current flowing north along its eastern coast (Ziegler et al., 1981) China was also warmer than other equatorial paleocontinents during early Devonian. Finally, we suggest that southeastern China was situated so that prevailing winds were ineffective in transporting spores westward toward Laurussia.

It is quite possible that current, widespread concepts of primitive vs. advanced character states are biased by the paleoecological conditions under which the first vascular plants lived. As we learn more about those that evolved on different parts of the Earth under different paleoecological conditions we may need to re-evaluate these concepts.

\section{Materials and methods}

The specimens were collected from the fifth lithological unit of the Posonchong Formation of Lower Devonian (Siegenian) age (see: Hao, 1989a, fig.1, 2 for a stratigraphic chart and p.165 for a discussion of this age designation). The section outcrops about $150 \mathrm{~m}$ west of Zhichang village, Gumu, on the west side of the highway leading from Wenshan to Maguan County in southeastern Yunnan.

The plant specimens were preserved largely as compressions in two thin-bedded layers, each about $3-5 \mathrm{~cm}$ thick. The lower layer is a dark gray mudstone, directly overlain by a light purple-gray argillaceous sandstone. Ten specimens containing dichotomously branched axes and numerous associated sporangia were collected. The four specimens from the upper layer contained several branching systems containing short axis segments permineralized by limonite.

Thirty transverse thin sections were prepared from 5 permineralized axis segments and numbered in sequence proximally to distally. These sections are identified as follows: HS11-1 (3 sections of a first-order axis); HB-4 (6 sections of a first-order axis): HB-1 (3 sections of a second-order axis); HB5 and HB6 (18 sections of a more distal part of a branching system; although numbered separately, these segments represent a single axis). Five longitudinal sections were prepared from two segments of first-order axes as follows: HS1 1-2 (1 section); HB-3 (4 sections). Sections, cut at $1 \mathrm{~mm}$ intervals, were prepared according to the technique of Stein et al., (1982). Attempts to clear the sections in reagent $\mathrm{HCl}$ were largely unsuccessful.

To obtain in situ spores, sporangia were uncovered and removed from the matrix using steel needles and macerated in a solution of $20 \% \mathrm{HF}$ for 24-48 h. After washing, $\mathrm{HCl}$ was added to remove calcium fluoride and the sludge was neutralized with sodium hydroxide, washed and mounted on glass slides.

Whereas the preparations described above were made primarily in the laboratory of CBB, a few sections (Plate III, 19-21) and the SEM photographs were made in the laboratory of HS in Beijing. Specimens were prepared for SEM observations as follows: Permineralized axis segments were broken transversely and longitudinally. Appropriate fragments, observed and chosen with aid of a light microscope, were mounted on stubs and gold coated for observation with an SEM. 


\section{Description}

\section{Morphology of vegetative axes}

The axes are $1.8-5.0 \mathrm{~mm}$ wide. The longest axis observed is $9.0 \mathrm{~cm}$ in length and it is broken at both ends. Branching is by isotomous dichotomy (Plate I, 1,2). Axes increase slightly in width just proximal to a dichotomy and the resulting pair of axes are nearly the same width or slightly narrower than the parent axis. For example, Plate I, 2 (upper right) shows an axis $3.2 \mathrm{~mm}$ wide which increases to $4.0 \mathrm{~mm}$ just below a dichotomy. The two resulting axes distal to the dichotomy are each about $3.0 \mathrm{~mm}$ wide. Dichotomies occur at wide angles of $50-70^{\circ}$ (Plate I, 1, 2). Occasionally 4-6 surface striations may be observed on the inner surface of a compression mold of an axis (Plate I, 2, arrows). Since they are not visible on the external surface of the compressed axes we interpret them to represent longitudinal strands of tissue in the outer cortex. The axes are sparsely covered by small spines that taper from a rather broad base (Plate I, 2; Fig. 1c). They project from the axes at angles of from $60-90^{\circ}$, and vary in length from $0.6-1.5 \mathrm{~mm}$, and in width at their bases of from $0.5-1.4 \mathrm{~mm}$.

In addition to the major branching axes just described, we have observed among them several small, slender dichotomous branching systems (Plate I, 1, arrow, 3; Fig.1a, b). These are comprised of axes only $0.1-0.3 \mathrm{~mm}$ wide, and one (Fig.1b) consists of two dichotomies that form angles of about $30^{\circ}$. The other (Plate I, 1, arrow, 3; Fig.la) bears terminally on one segment of the dichotomy a carbonaceous fragment that we interpret to be the basal region of a sporangium.

\section{Morphology of sporangia}

Abundant isolated sporangia are preserved in the matrix of several specimens. Some are associated with compressed vegetative axes (Plate I, 1), others with the axes containing permineralized segments. Sporangia from these two sources are identical. They range in size from $2.2-5.1 \mathrm{~mm}$ (generally $3.6-4.6 \mathrm{~mm}$ ) long and $1.3-3.5 \mathrm{~mm}$ (generally $1.5-2.3 \mathrm{~mm}$ ) wide. In shape they vary from elongate-elliptical to ovoid with a rounded apex and often narrow toward the base (Plate I, 4-6; Fig. 1d-m). Some still bear the slender basal stalks by which they were attached to the fertile branch system. These short stalks, of variable length, measure $0.1-0.3 \mathrm{~mm}$ in width. Some sporangia exhibit a peripheral rim, possibly thickened in life, about $0.07 \mathrm{~mm}$ wide, which extends from near the base over the apex (Plate I, 6, arrows; Fig.1e, g, m). Longitudinal dehiscence apparently occurred along this zone separating the sporangia into two equal valves (Plate I, 4, 5; Fig. $1 \mathrm{~h}, \mathrm{j}-1$ ). Occasionally, sporangia occur in pairs (Plate I, 1), suggesting the manner in which they were borne on the plant.

\section{Spores}

Poorly preserved masses of spores (Plate IV, 28) and isolated spores were obtained from sporangia by maceration. The spores, generally circular in equatorial outline, range from $35.3-53.3 \mu \mathrm{m}$ in diameter. The trilete scar is simple, thin, often split open and each ray extends over one half or more of the spore radius. The spore exine is smooth or finely ornamented.

\section{Anatomy: Histology}

Segments of permineralized axes are, in general, poorly preserved. Only thick-walled outer cortex and primary xylem are present, other tissues having decayed prior to permineralization. Some axes are so badly compressed that the preserved cortex is in contact with the primary xylem, and extends laterally along the bedding plane as two prominent "wings" (Plate II, 7-9). Some other axes are less compressed and retain an oval configuration in transverse section (Plate II, 10; Fig.2). It seems likely that in life these axes were circular. Even in the most highly compressed axes, the xylem column shows relatively little evidence of compression and varies in transverse configuration from circular to oval (Plate II, 7-9). Although in a few cases the oval form may have resulted from compression (Plate II, 8), we believe that in most it is a precocious indication of branching of the stele prior to the next dichotomy of the axis. In regions 


\section{PLATE I}
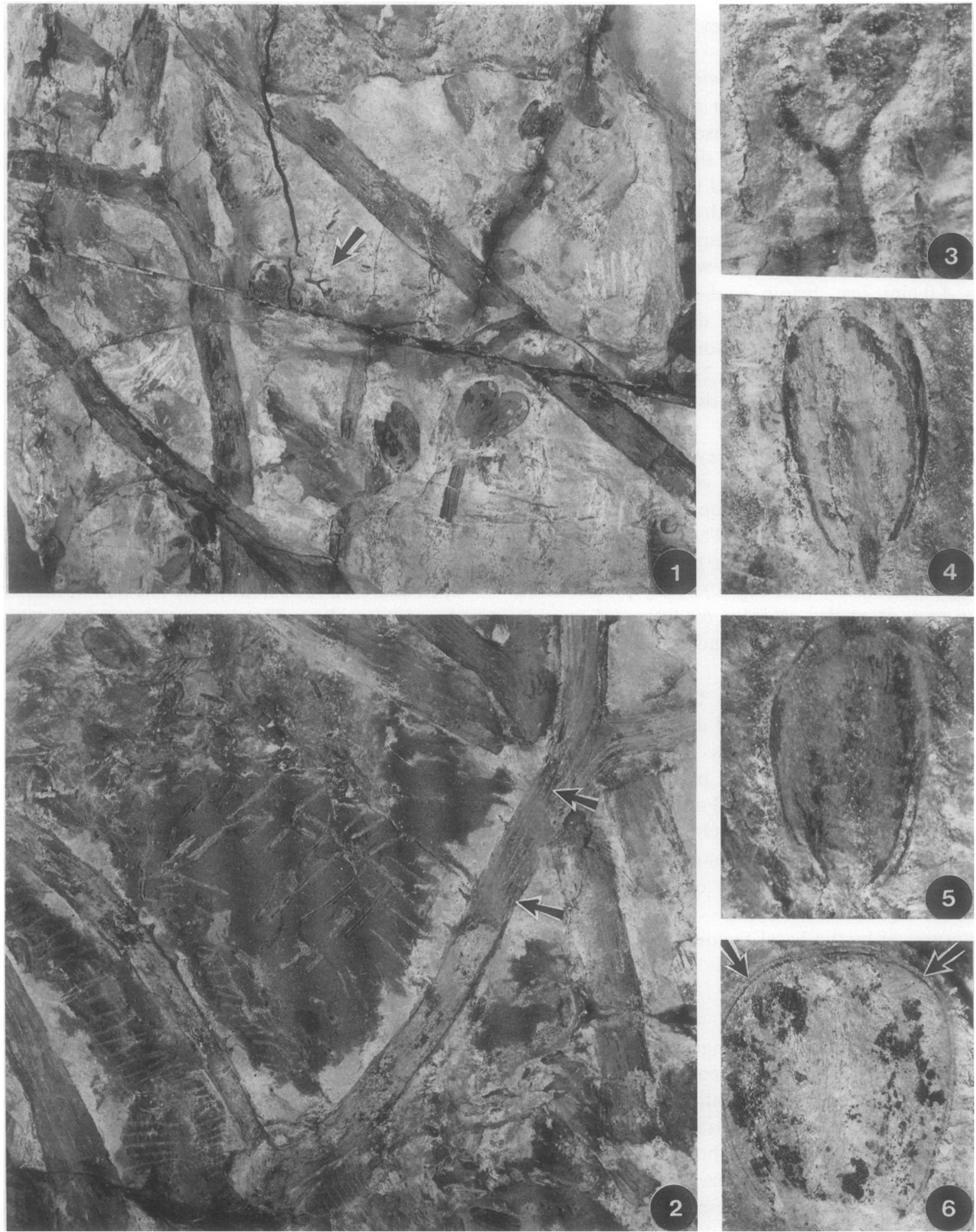


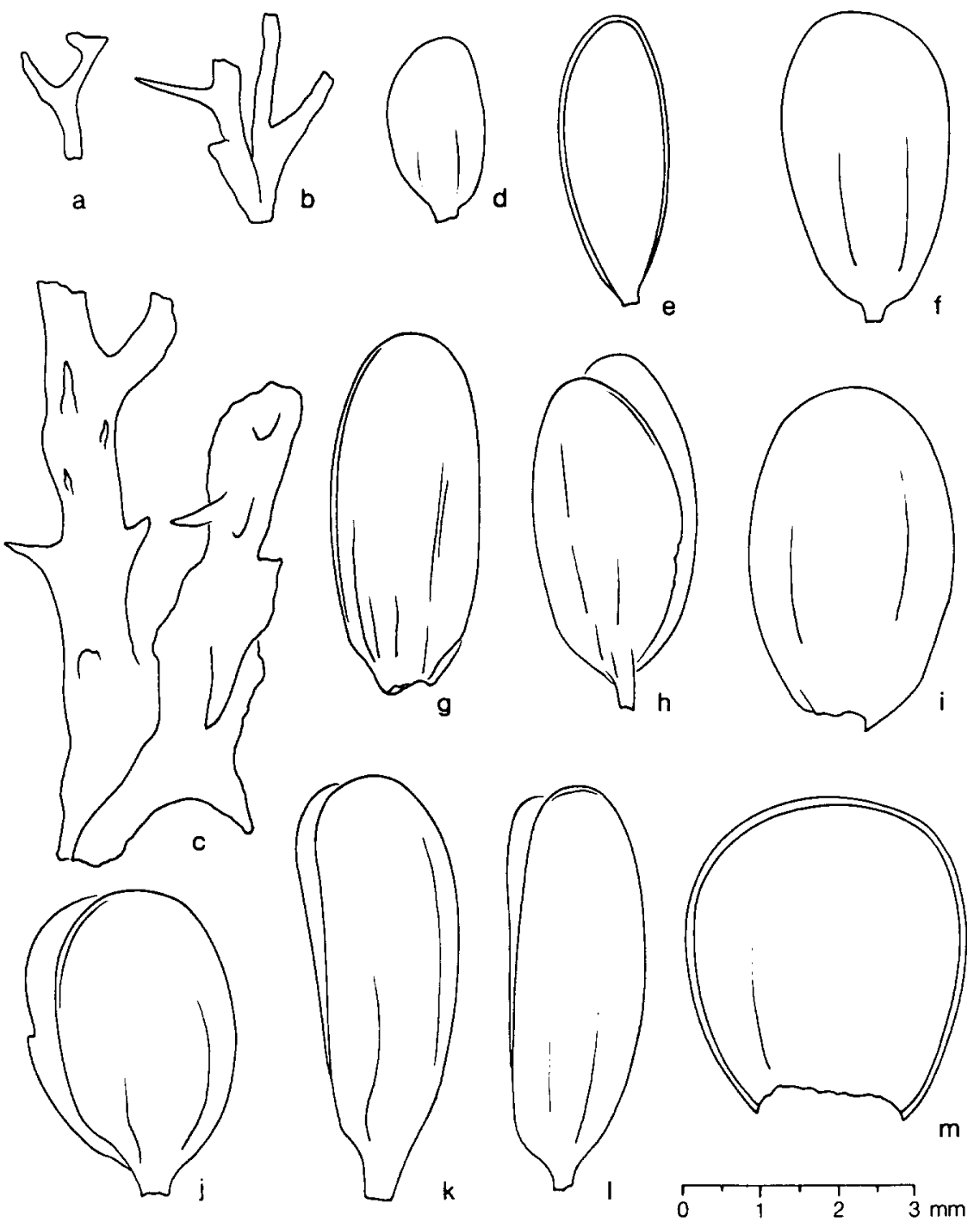

Fig.1. Yunia dichotoma. Camera lucida drawings of small branch systems $(\mathrm{a}-\mathrm{c})$ and sporangia $(\mathrm{d}-\mathrm{m})$, some having dehisced and showing two valves.

proximal to those in which the primary xylem column begins to bifurcate it is circular in transverse shape (Plate II, 7; Plate III, 15) with a diameter of $807-1076 \mu \mathrm{m}$. As viewed in transverse section, it commonly contains two somewhat irregularly elongate, or lunate, to roughly circular parenchymatous regions (Plate II, 7-13; Plate III, 14-21; Plate IV, 24, 29) with associated

\section{PLATE I}

\footnotetext{
1-6. Yunia dichotoma

1. Some axes and isolated sporangia. Note small, fertile, dichotomous branch, enlarged in fig.3. BUHB-11-1 (Holotype). $\times 2.3$.

2. Axes exhibiting dichotomous branching. Note striations (arrows) and spines. BUHB-11-2. $\times 2.3$.

3. Dichotomous branch system bearing base of one sporangium. $\times 10$.

4-6. Isolated sporangia showing evidence of longitudinal dehiscence $(4,5)$ and peripheral rim (6). BUHB-11-3, 4. $\times 11.3$
} 


\section{PLATE II}
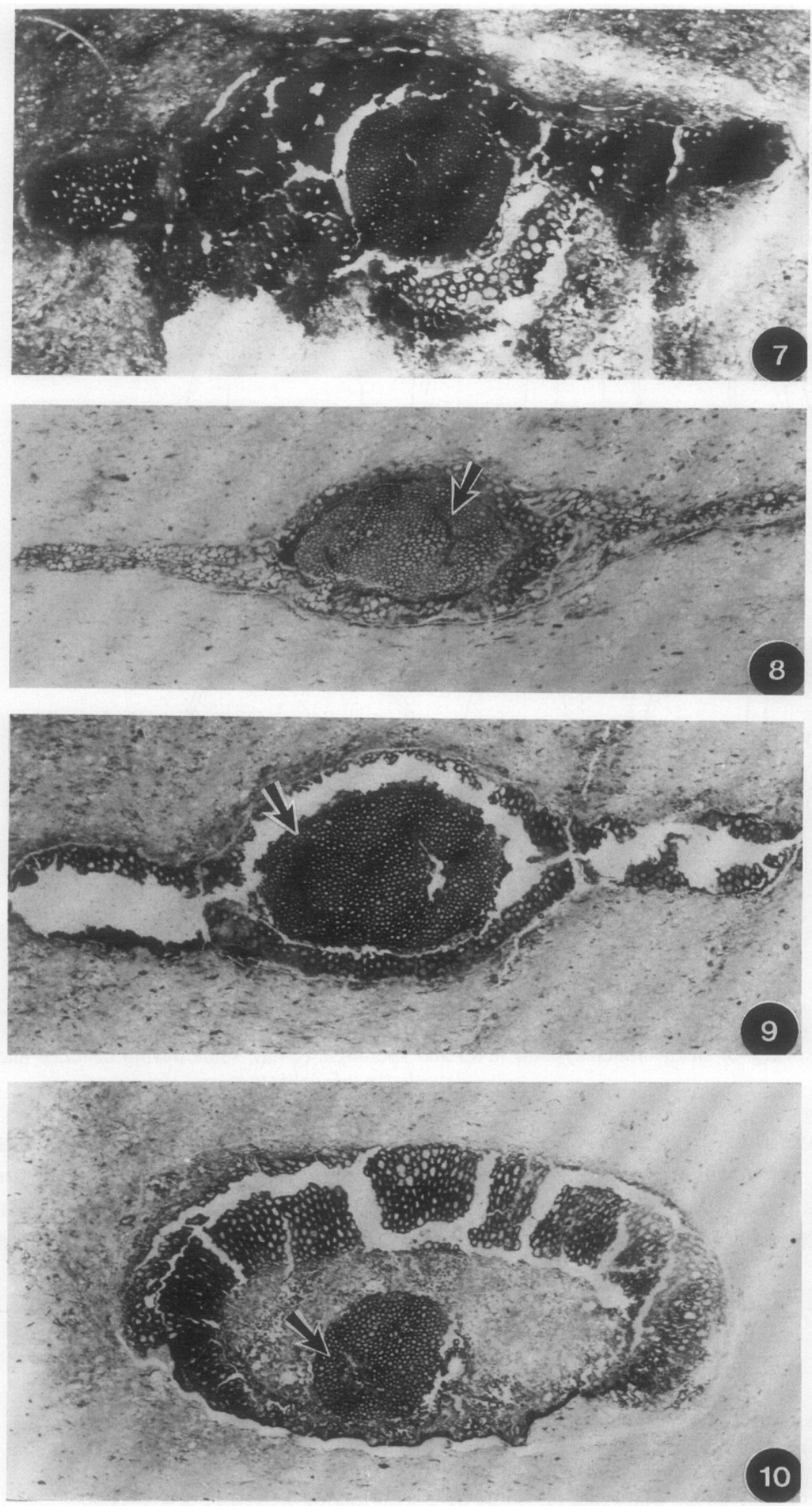

10
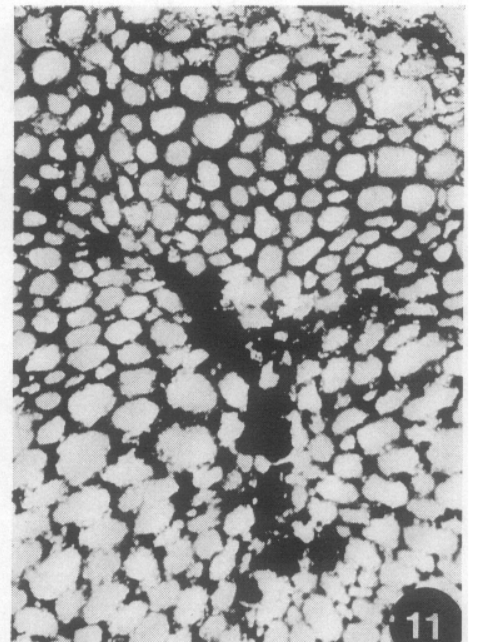

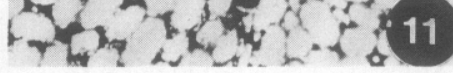
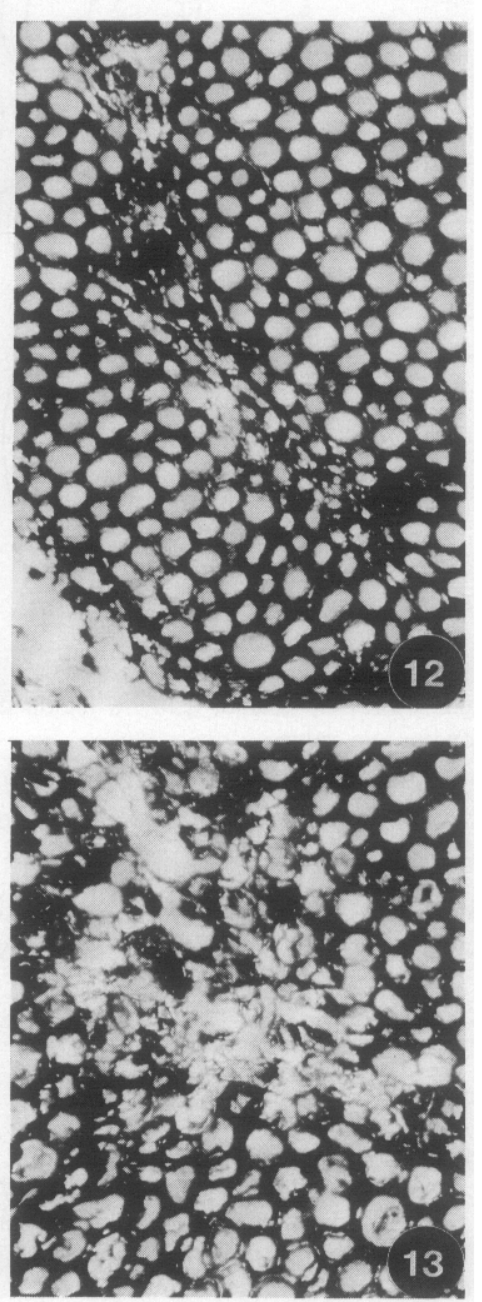
PLATE III
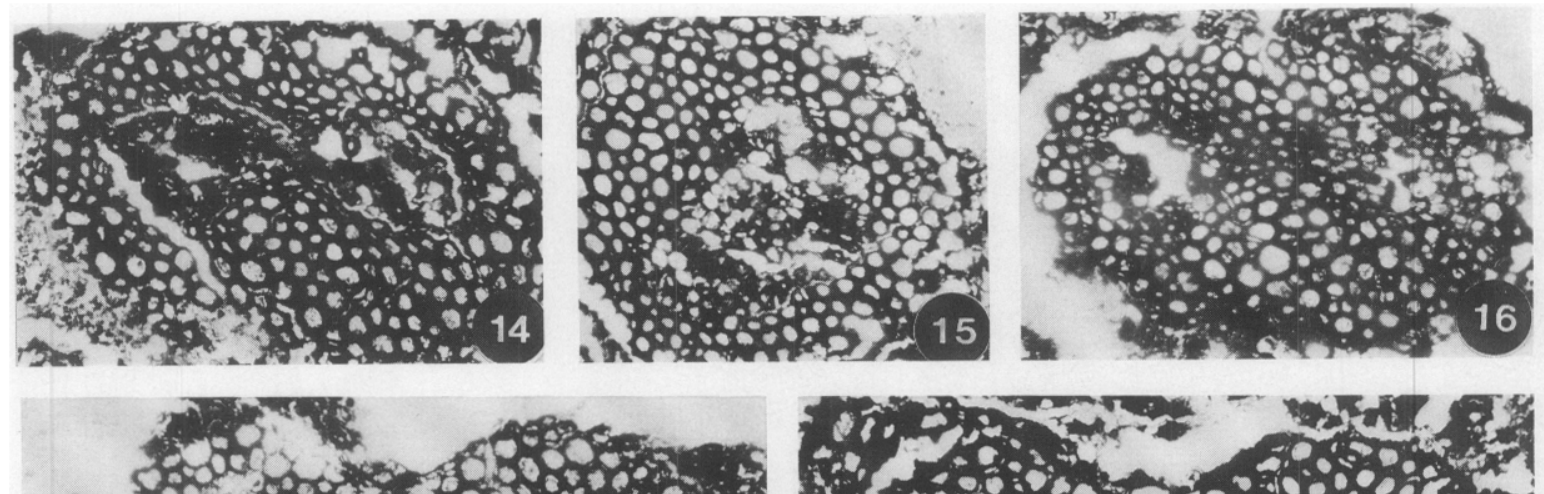

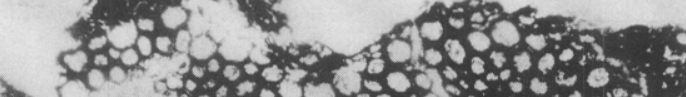

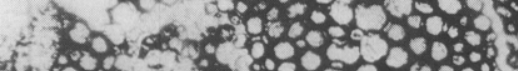

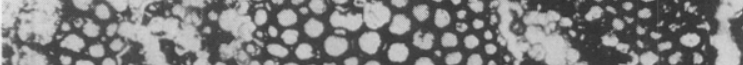

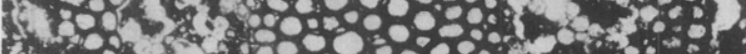
m

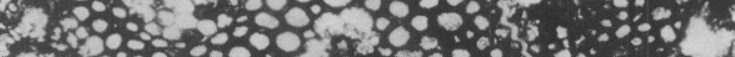

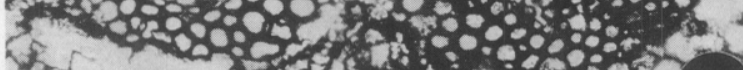

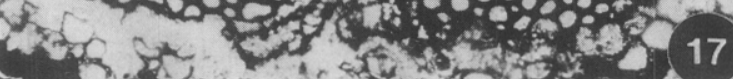
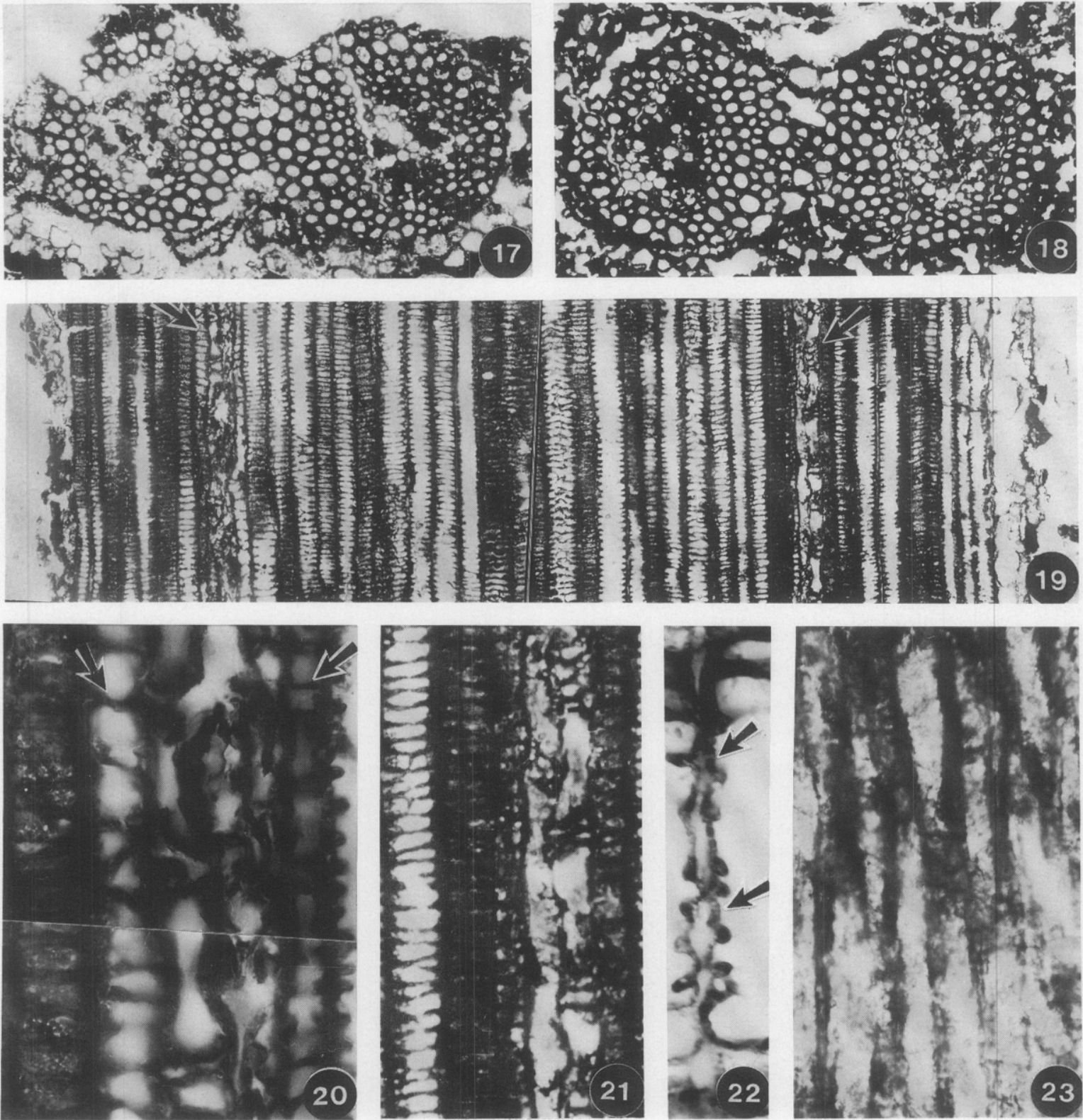

(for description see p. 189) 


\section{PLATE IV}
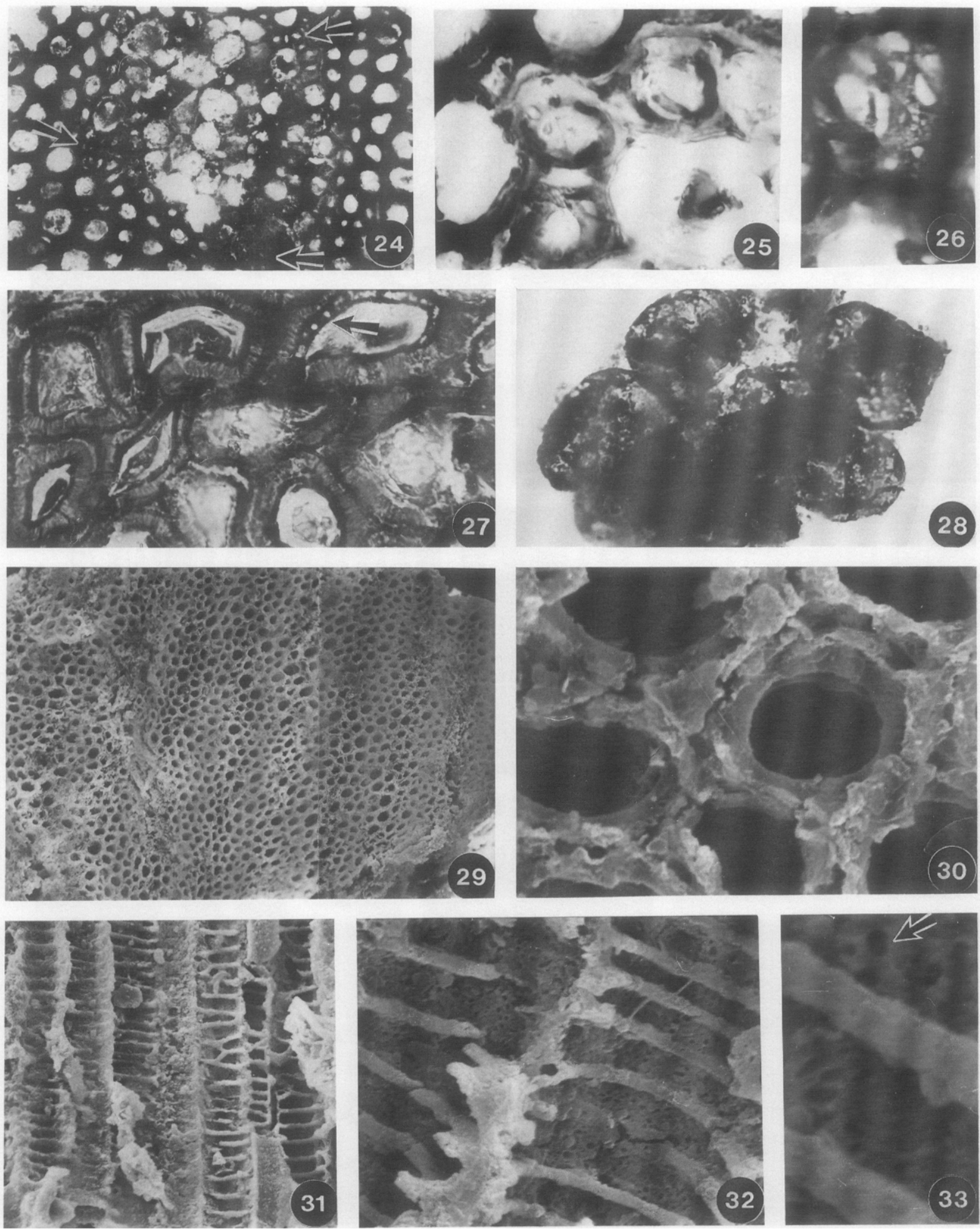
small tracheids. These regions, also conspicuous in longitudinal sections (Plate III, 19, arrows), sometimes assume a three-angled configuration (Plate II, 11), but this may be the result of compression. Although these columns of parenchyma with their associated strands of small tracheids are quite large, $370-452 \mu \mathrm{m}$ long and $46-60 \mu \mathrm{m}$ wide in transverse dimensions when lunate in form, and varying from $205-460 \mu \mathrm{m}$ in diameter when circular, we interpret them (parenchyma plus tracheids) to comprise protoxylem strands. Just distal to bifurcation, each primary xylem column contains a single protoxylem strand (Fig. $2 \mathrm{a}-\mathrm{c}$ ). Thus development of primary xylem was centrarch.

Protoxylem parenchyma cells are irregularly polygonal in transverse shape and vary in diameter from about 5.0-25.0 $\mu \mathrm{m}$ (Plate II, 12, 13: Plate IV, 24). End walls containing simple pits are occasionally visible (Plate IV, 26). In longitudinal view parenchyma cells are commonly roughly rectangular but sometimes have rounded ends (Plate III, 19-21) and vary in length from $8.3-35.4 \mu \mathrm{m}$. Protoxylem tracheids occur in peripheral strands and, possibly, intermixed with the parenchyma. Whereas their distribution in the protoxylem strand is unclear, in one instance they seem to be largely aggregated in three peripheral strands (Plate IV, 24, arrows). Protoxylem tracheids vary in diameter from 11.5-16.8 $\mu \mathrm{m}$. We have not been able to determine the nature of wall sculpturing with certainty, but believe that it is probably annular and/or helical (Plate II, 20, arrows).

PLATE II (see p. 186)

7-13. Yunia dichotoma

7. Transverse section interpreted to be from level just distal to dichotomy of the axis. Note pair of lunate (in section) protoxylem strands in the xylem column. Section HS11-1. $\times 27$.

8, 9. Transverse sections showing elliptical primary xylem columns containing pairs of lunate protoxylem strands. Form of xylem columns suggest levels closer to the next distal dichotomy than that shown in preceding figure. Arrows indicate regions of protoxylem enlarged in figs. 11 and 12 . Slides HB4-2, 4. $\times 27$.

10. Transverse section of axis showing cortex and primary xylem column roughly circular in section. Arrow indicates protoxylem strand enlarged in fig.13. HBI-2. $\times 27$.

11-13. Enlargements of protoxylem strands indicated by arrows in figs.8-10. $\times 167, \times 167, \times 180$.

PLATE III (see p. 187)

14-23. Yunia dichotoma

14-18. Selected transverse sections of the primary xylem columns showing the form and histology of the protoxylem strands through a region of dichotomy. Figures 14, 15: Slide HB5-4; figs.16-18: HB5-6, HB6-2, 4. $\times 90$.

19. Longitudinal section through primary xylem column. Arrows indicate protoxylem strands, parts of which are enlarged in figs. 20 and 21 . Slide HS1 1-2. $\times 142$.

20,21. Detail of protoxylem strands showing parenchyma cells and possible protoxylem tracheids with annular and/or helical wall sculpturing. $\times 406$.

22. Sectional view of walls of contiguous metaxylem tracheids showing perforations in presumed primary wall (arrows) between secondary wall bars. Slide HS11-2. $\times 406$.

23. Cells of the cortex in longitudinal section. Slide HB3-2. $\times 120$.

\section{PLATE IV}

24-33. Yunia dichotoma

24. Transverse section of a protoxylem strand showing central parenchyma and peripheral protoxylem tracheids (arrows). Slide HB6-3. $\times 235$.

25. Enlargement of area indicated by upper, right arrow in fig. $24 . \times 1217$.

26. Transverse section of a parenchyma cell from protoxylem strand showing end wall with simple pits. HB6-3. $\times 1217$.

27. Cortical cells in transverse view showing walls possibly expanded by crystallization. HB1 $-2 . \times 542$.

28. A cluster of spores. HS11-1. $\times 600$.

29. A xylem column in transverse section. HS11-21. $\times 100$

30. Transverse section of metaxylem showing annular or helical wall thickenings. HS11-35. $\times 1400$.

31-33. Metaxylem tracheids in longitudinal view showing probable helical and reticulate wall sculpturing with perforations in the presumed primary wall between (figs.32, 33). HS11-31, HS11-24, HS11-25. $\times 400, \times 1750, \times 7000$. 

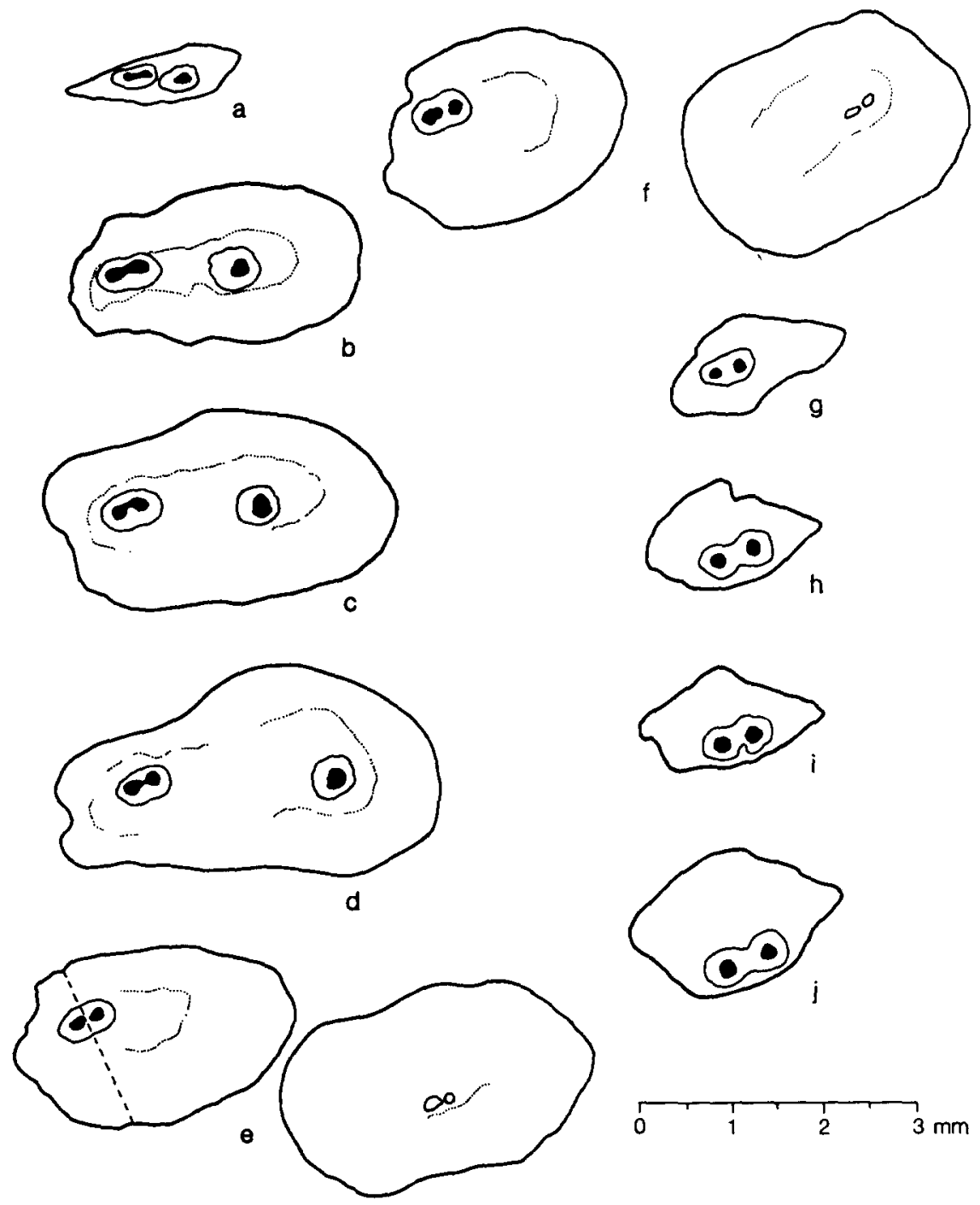

h
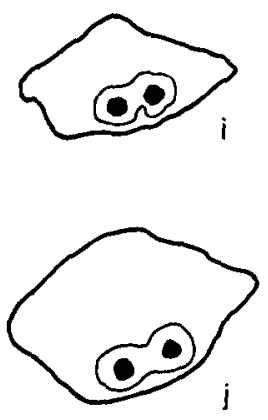

Fig.2. Yunia dichotoma. Camera lucida drawings of a series of selected sections showing stages in branching. Black areas represent protoxylem. From specimens HB5 and HB6. The dashed line in fig.2e indicates a break in the section.

Metaxylem tracheids are polygonal, often hexagonal, in transverse shape and vary in diameter from 13.8-39.5 $\mu \mathrm{m}$ (Plate II, 12, 13; Plate IV, 29,30). Wall sculpturing might be primarily of the type described as annular by Edwards et al. (1989) (Plate IV, 30). We believe that it might also be tightly helical as well as scalariform and scalariform-reticulate (Plate IV, 31-33). The secondary wall bars or helices are separated by a distance of $2.0-4.0 \mu \mathrm{m}$ and are about $1.0-2.0 \mu \mathrm{m}$ in thickness. The apparent primary wall between them is perforated by small, ran- domly arranged, circular to oval pores, $0.1-0.5 \mu \mathrm{m}$ in diameter (Plate III, 22, arrows; Plate IV, 32, 33, arrow).

The preserved outer cortex occupies a region up to $564 \mu \mathrm{m}$ wide (Plate III, 10). Cortical cells, in transverse view, are polygonal and vary from $31.3-75.0 \mu \mathrm{m}$ in diameter. The walls are commonly very thick, up to $8.0 \mu \mathrm{m}$ (Plate IV, 27), but may have been unnaturally expanded by crystal formation in some specimens (Plate IV, 27). These cells are elongate (they may exceed $82.0 \mu \mathrm{m}$ ) and have tapering ends (Plate III, 23). 


\section{Anatomy: Branching patterns}

We believe that branching of the stele, and ultimately, of an axis, is indicated by the plane of division of the protoxylem strands. Thus in two sections selected from a series of six (Plate II, 8, 9) the predicted plane of division is one essentially parallel with the top and bottom of these photographs. Note also that the stele has become extended in the same plane. We conclude, therefore, that the stelar column, circular in transverse section, in the axis pictured in Plate II, 7 (from a different series) represents a more proximal level in an axis of about the same size.

Another series of sections (Fig. $2 \mathrm{a}-\mathrm{j}$ ) illustrates additional stages in the branching of an axis. Following bifurcation of the stelar column and prior to branching of the axis, the protoxylem strand in the xylem column on the left begins to divide by elongating transversely and becoming conspicuously bilobed (compare the stelar columns in Fig. 2b with photographs of the same columns in Plate III, 14, 15 and the left column of Fig.2d with that in Plate III, 16). At more distal levels (Fig. $2 \mathrm{e}, \mathrm{f})$ the protoxylem strand completes its division in the left xylem column and the axis has divided into two. The right stele (Fig.2d) shows no signs of division and the protoxylem strand is roughly circular in transverse section. Unfortunately, this xylem column is preserved only as two small fragments in the most distal sections. Whereas this difference in levels of branching suggests that dichotomy in Yunia was not strictly isotomous, the bulk of evidence indicates that it was predominantly isotomous.

Continuing through this series of sections (Fig. $2 \mathrm{~g}-\mathrm{j}$ ), the stele of the left axis of the dichotomy continues to branch and at a level just distal to that illustrated in Fig. $2 \mathrm{j}$ and Plate III, 18, stelar bifurcation is complete and each column has a single centrarch protoxylem strand.

We assume that in more proximal parts of the plant - at levels just distal to stelar branching, but prior to dichotomy of the axis - each xylem column would also contain a single, central protoxylem strand. Unfortunately, we do not know over what distance in the axes this condition persists. Since, however, many axis segments that we have sectioned contain stelar columns with two lateral protoxylem strands, we believe the division of the central protoxylem strand occurs quite close to the level of stelar branching.

In apparent apical regions where dichotomies are closely spaced (Fig.2a-j) the protoxylem strands seem to be in a "constant" state of division and the occurrence of a pair of protoxylem strands in a stelar column (Fig.2f,g) persists for only a very short distance. However, we believe that pairs of protoxylem strands persisted over longer distances in more basal regions of the plant where successive stelar and axial dichotomies were more widely spaced (Plate II, 7-9).

Division of the protoxylem and, subsequently, the xylem column, are precocious reflections of, and also indicate the plane of, the next dichotomy. We believe successive dichotomies occurred in planes at $90^{\circ}$ to each other, and that dichotomy was, therefore, cruciate. Evidence for cruciate dichotomy is presented in Fig.3. We interpret the distortion of the angles between successive dichotomies reflected in this drawing of the disposition of axes in the matrix to be the result of compression by sediment and consequent displacement. Further evidence is the apparently narrow basal region of the axis forming the left side of the dichotomy in the lower part of Plate I, 2. This suggests that it has been twisted from a plane more nearly perpendicular to that of the following dichotomy (upper right part of this photograph) by compression.

\section{Diagnoses}

\section{Yunia, gen. nov.}

Plant consisting of spiny axes characterized by cruciate dichotomy. Associated (but not attached) sporangia elongate-elliptical or elongate-ovoid, occasionally clustered in pairs and possibly borne terminally on dichotomous branches; dehiscence longitudinal along a narrow, marginal rim, splitting the sporangia into two equal valves. Plant probably homosporous. Primary xylem comprising a haplostele with a large, central, highly parenchymatous protoxylem strand with peripheral tracheids which divides prior to bifurcation of the stele to 


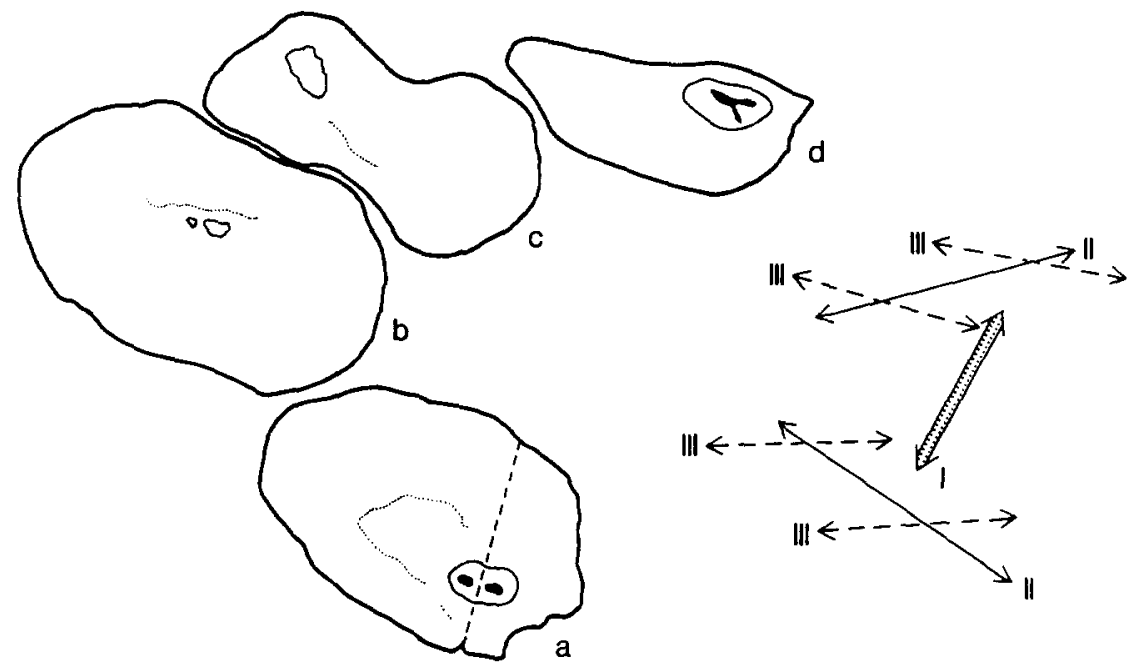

Fig.3. Yunia dichotoma. Camera lucida drawing of one section (HB5-7) illustrating a pattern of cruciate dichotomy. Planes of division are indicated by arrows: $I=$ first division, $I=$ second, $I I=$ third.

form a pair of protoxylem strands. Protoxylem strands roughly circular in smaller axes, but often appearing lunate in transverse form in the stele of larger axes.

\section{Yunia dichotoma sp. nov.}

Characteristics as for the genus. Spiny axes $1.8-5.0 \mathrm{~mm}$ wide. Angle of branching $50-70^{\circ}$. Successive dichotomies at least $3.8 \mathrm{~cm}$ apart. Possible terminal fertile axes $0.1-0.3 \mathrm{~mm}$ wide, dichotomizing at an angle of about $30^{\circ}$; dichotomies closely spaced, about $1.2 \mathrm{~mm}$ apart. Spines triangular, tapering to a point, $0.6-1.5 \mathrm{~mm}$ long and $0.5-1.4 \mathrm{~mm}$ wide at the base, projecting from the axes at angles of from $60-90^{\circ}$ and sparsely distributed. Associated sporangia 2.2-5.1 mm long (commonly $3.6-4.6 \mathrm{~mm}$ ) and $1.3-3.5 \mathrm{~mm}$ wide (commonly $1.5-2.3 \mathrm{~mm}$ ) characterized by a peripheral rim $0.07 \mathrm{~mm}$ wide. The protostele, $807-1076 \mu \mathrm{m}$ in diameter, contains one or two protoxylem strands, $205-460 \mu \mathrm{m}$ in diameter when circular in transverse section, $370-452 \mu \mathrm{m}$ long by 46-60 $\mu \mathrm{m}$ wide when lunate. Protoxylem parenchyma cells polygonal in section, $5.0-25.0 \mu \mathrm{m}$ in diameter and 8.3-35.4 $\mu \mathrm{m}$ long. Protoxylem tracheids characterized by annular and/or helical wall sculpturing; 11.5-16.8 $\mu \mathrm{m}$ in diameter. Metaxylem tracheids with annular, helical, helical- and/or scalariform-reticulate and possibly scalariform wall sculpturing; $13.8-39.5 \mu \mathrm{m}$ in diameter. Bars and/or helices of presumed secondary wall material $1.0-2.0 \mu \mathrm{m}$ wide and separated by $2.0-4.0 \mu \mathrm{m}$. Presumed primary wall between bars and/or helices containing small, randomly arranged, circular to oval pores (or possibly simple pit-pairs if some secondary wall covers primary wall) $0.1-0.5 \mu \mathrm{m}$ in diameter. Spores $35.3-53.3 \mu \mathrm{m}$ in diameter, smooth or with finely granular exine sculpturing; commonly folded; trilete marks thin, simple and extending at least $1 / 2$ of spore radius.

Derivation of name: The generic name, Yunia, is derived from Yun, a colloquial abbreviation of Yunnan, the Chinese province from which the fossil plant material was collected. The specific epithet, dichotoma, describes the branching pattern of the plant.

Holotype: Specimen BUHB-1101, Plate I, 1.

Paratypes: Specimens BUHB-1102, Plate I, 2; BUHB-1103, Plate I, 4, 5; HS11-1, Plate II, 7; HB4-2, 4, Plate II, 8, 9; HB1-2, Plate II, 10; HB54, 5, 6, Plate III, 14-16; HB6-2, 4, Plate III, 17, 18; HS11-2, Plate III, 19.

Type specimens and all other illustrated specimens are deposited in the paleobotanical collections, Department of Geology, Peking University, Beijing, China. 
Type Locality: Mountain outcrop approximately $150 \mathrm{~m}$ west $\mathrm{Zhichang}$ village, Wenshan district, Yunnan province, China.

Age: Late Siegenian

Horizon: Unit five of Posonchong Formation (See stratigraphic column in Hao, 1989a, fig.2.)

\section{Discussion and comparisons}

\section{Trimerophytalean affinity}

Uncertainty about the mode of attachment of sporangia, and lack of proof that the associated sporangia were actually borne on Yunia, makes comparison with other taxa more difficult than it would otherwise be. If our hypothesis, that the sporangia do belong to Yunia and were borne in pairs on terminal dichotomous branching systems, is correct, we can conclude that this plant resembled members of the Trimerophytales such as Psilophyton and Pertica (Kasper and Andrews, 1972). In shape, however, the rounded apices of the sporangia associated with Yunia differ from the pointed apices of those of Psilophyton and Pertica. The isotomous to anisotomous dichotomy of Yunia is also consistent with the characteristics of trimerophytes although branching in this group is predominantly anisodichotomous to pseudomonopodial. It should be noted also that the sporangia associated with Yunia resemble, in their rounded apices and occasionally obovate form and possibly thickened peripheral rims, those of some rhyniophytes and zosterophyllophytes. Whereas most zosterophyllophytes, such as Zosterophyllum (see Gensel and Andrews, 1984) and Sawdonia (Hueber, 1971), have reniform, transverse elliptical or globose sporangia; others, such as Deheubarthia splendens (Edwards et al., 1989), have an elongate-elliptical shape strikingly similar to those of Yunia, although their lateral mode of attachment is very different from that hypothesized for Yunia. Rhyniophytes such as Cooksonia caledonica (Edwards, 1970), Renalia hueberi (Gensel, 1976) and Hsua robusta (Li, 1982) also have reniform sporangia, borne singly and terminally on dichotomous branch systems, that differ from those presumed to belong to Yunia. All, like Yunia, however, bore sporangia with possibly thickened, distal rims.
Yunia differs from other early land vascular plants in some aspects of anatomy - in particular the structure and histology of its primary xylem column. The most conspicuous differences are the large size of the protoxylem strand, and the large amount of parenchyma it contains. The presence in the xylem column of two protoxylem strands over long distances in some axes is another, but superficial difference. It should be noted, however, that the presence of a single protoxylem strand in the protostele immediately following its bifurcation resembles the centrarch condition in rhyniophytes such as Rhynia gwynne-vaughanii (Kidston and Lang, 1917) and Hsua (Li, 1982) and trimerophytes such as Psilophyton princeps (Hueber and Banks, 1967), P. dawsonii (Banks et al., 1975) and P. charientos and P. forbesii (Gensel, 1979). Of these, $P$. dawsonii is the best known anatomically. It is characterized by a haplostele with a single, central protoxylem strand, consisting in larger axes of helical and scalariform tracheids, but without any apparent protoxylem parenchyma.

During the process of branching in $P$. dawsonii, bifurcation of the protoxylem and the stele precede dichotomy of the axis. In Yunia, branching of the stele is also reflected first in the branching of the protoxylem and occurs precociously proximal to the level at which the stem dichotomizes.

Another similarity between Psilophyton and Yunia is the presence in the tracheids of each of small pit-like regions, or perforations, in the wall between bars or helices of secondary wall thickenings.

Yunia is clearly more similar to the trimerophytes than to any other Lower Devonian group and we tentatively assign it to this order.

\section{Origin of ferns}

The origin of the ferns is a problem of wide interest. Stewart (1983) suggested that all ferns may be ultimately derived from the Trimerophytales. Recently, Holmes (1989) has proposed an origin of the filicalean taxa, Anachoropteridaceae, Botryopteridaceae and Psalixochlaenaceae from this group. Stewart comments on the similarities in branching patterns and Holmes emphasizes similarities in stelar morphology. 
Many Carboniferous ferns, including members of both the Zygopteridales and the Filicales, are characterized by centrarch or mesarch haplosteles. Excellent examples from among Lower Carboniferous zygopterid ferns are Diplolabis romeri (Gordon, 1911a) and Metaclepsydropsis duplex (Gordon, 1911b). The primary xylem column of D. romeri consists of a peripheral zone of large tracheids and a central zone of much smaller tracheids. Gordon does not mention the presence of protoxylem strands in the stem stele. We assume that they were present, however, but it is impossible to determine the number and their position on the basis of his photographs. It seems likely that development of primary xylem was mesarch and the protoxylem strands were located within or on the periphery of the zone of small, central tracheids. In $M$. duplex the primary xylem column also contains a central region of small cells - a mixture of tracheids and parenchyma cells. Again, Gordon is unclear on the nature and position of protoxylem in the stem, but his photographs suggest strongly that there were several strands of protoxylem tracheids located around the periphery of the central region. Gordon $(1911 \mathrm{a}, \mathrm{b})$ notes that the series of stelar types represented in Diplolabis and Metaclepsydropsis suggests the evolution of the fern siphonostele by "vitalization" (not Gordon's term) of a protostele.

The three filicalean families studied by Holmes (1989) are all characterized by protosteles with mesarch development of primary xylem. Interestingly, genera from two of these families, Botryopteris dichotoma (Holmes and Galtier, 1983) and Psalixochlaena cylindrica (Holmes, 1977) have haplosteles consisting of an outer zone of large-celled tracheids and an inner zone of small tracheids with which several protoxylem strands are associated.

Features of the stelar xylem column - histology, form, size and manner of branching - in these zygopterid and filicalean genera are of particular interest because they are so similar to those of Yunia. We have interpreted the central parenchymatous region of Yunia to represent protoxylem parenchyma of a single, centrarch protoxylem strand because of the general resemblance of the stele to those of other Devonian trimerophytes and rhyniophytes. Whereas the
Carboniferous genera with similar stelar morphology have been interpreted differently, the similarities are sufficient to suggest a possible genetic relationship between Yunia and these primitive ferns. Indeed, the relatively large, central parenchymatous region of the Yunia stele could be interpreted as a primitive pith similar to that of Metaclepsydropsis duplex. The stelar anatomy of Yunia thus supports the view of those who believe that the zygopterid ferns had their origin in the Trimerophytales. It also supports and strengthens the viewpoint of Holmes (1989) that the Carboniferous Filicales were derived from the Trimerophytales.

\section{Acknowledgements}

This study was supported by a combined grant from the Natural Science Foundation of China and the Chinese Foundation for Development of Geological Sciences and Techniques. Support for the project was also provided by the Center for Chinese Studies and the Museum of Paleontology of the University of Michigan where most of the research was done and the manuscript prepared. The line drawings were finished by Bonnie Miljour of the Museum of Paleontology.

\section{References}

Bambach, R.K., Scotese, C.R. and Ziegler, A.M., 1980. Before Pangea: the geographies of the Paleozoic world. Am. Sci., 68 : 26-38.

Banks, H.P., 1968. The early history of land plants. In: E.T Drake (Editor), Evolution and Environment. Yale Univ. Press, New Haven, Conn., pp.73-107.

Banks, H.P., 1975. Reclassification of Psilophyta. Taxon, 24: $401-413$.

Banks, H.P.. Leclercq, S. and Hueber, F.M., 1975. Anatomy and morphology of Psilophyton dawsonii, sp. nov. from the late Lower Devonian of Quebec (Gaspe) and Ontario, Canada. Paleontogr. Am., 8: 77-127.

Bierhorst, D.W., 1960. Observations of tracheary elements Phytomorphology, 10: 249-305.

Edwards, D., 1970. Fertile Rhyniophytina from the Lower Devonian of Britain. Palaeontology, 13: 451-461.

Edwards, D., Kenrick, P. and Carluccio, L.M., 1989. A reconsideration of cf. Psilophyton princeps (Croft and Lang, 1942), a zosterophyll widespread in the Lower Old Red Sandstone of South Wales. Bot. J. Linn. Soc., 100: 293-318.

Fang, Wu, 1989. Paleozoic paleomagnetism of the South China Block and the Shan Thai Block: the composite nature of southeast Asia. Diss., Univ. Michigan, Ann Arbor. 
Fang, Wu, Van der Voo, R. and Liang, Qizhong, 1989. Devonian paleomagnetism of Yunnan province across the Shan Thai-South China suture. Tectonics, 8: 939-952.

Geng. Bao-Yin, 1983. Stachyophyton gen. nov. discovered from the Lower Devonian of Yunnan and its significance. Acta Bot. Sin., 25: 574-579 (in Chinese, with an English abstract)

Geng. Bao-Yin, 1985. Huia recurvata - a new plant from Lower Devonian of southeastern Yunnan, China. Acta Bot. Sin., 27: 419-426 (in Chinese, with an English abstract)

Gensel, P.G., 1976. Renalia hueberi, a new plant from the Lower Devonian of Gaspe. Rev. Palaeobot. Palynol., 22: 19-37.

Gensel, P.G., 1979. Two Psilophyton species from the Lower Devonian of eastern Canada with a discussion of morphological variation within the genus. Palaeontographica, 168B: $81-91$.

Gensel, P.G., 1984. A new Lower Devonian plant and the early evolution of leaves. Nature, 309: 785-787.

Gensel. P.G. and Andrews, H.N., 1984. Plant Life in the Devonian. Praeger, New York, 381 pp.

Gordon, W.T., 19lla. On the structure and affinities of Diplolabis romeri (Solms). Trans. R. Soc. Edinburgh, 47: $711-736$.

Gordon, W.T., 191lb. On the structure and affinities of Metaclepsydropsis duplex (Williamson). Trans. R. Soc. Edinburgh, 48: 163-190.

Grierson, J.D. and Banks, H.P., 1963. Lycopods of the Devonian of New York state. Palaeontogr. Am., 4: 217-290.

Hao, Shou-Gang, 1988. A new Lower Devonian genus from Yunnan, with notes on the origin of leaf. Acta Bot. Sin., 30: 441-448 (in Chinese, with an English abstract).

Hao, Shou-Gang, 1989a. A new zosterophyll from the Lower Devonian (Siegenian) of Yunnan, China. Rev. Palaeobot. Palynol., 57: 155-171.

Hao, Shou-Gang, 1989b. Gumuia - a new genus of the Lower
Devonian from Yunnan. Acta Bot. Sin., 31: 954-961 (in Chinese, with an English abstract).

Hao, Shou-Gang and Beck, C.B., in press. Catenalis digitata, gen. et sp. nov., a plant from the Lower Devonian (Siegenian) of Yunnan, China. Can. J. Bot.

Holmes, J.C., 1977. The Carboniferous fern Psalixochlaena cylindrica as found in Westphalian $A$ coal balls from England. Part I. Structure and development of the cauline system. Palaeontographica, 164B: 33-75.

Holmes, J.C., 1989. Anomalous branching patterns in some fossil Filicales: implications in the evolution of the megaphyll and the lateral branch, habit and growth pattern. Plant Syst. Evol., 165: 137-158.

Holmes, J.C. and Galtier, J., 1983. Morphology and evolution of Botryopteris, a Carboniferous age fern. Part III. Botryopteris dichotoma. a new Westphalian species from Belgium with observations on other species. Palaeontographica, 186B: 1-17.

Hueber, F.M., 1971. Sawdonia ornata: a new name for Psilophyton princeps var. ornatum. Taxon, 20: 641-642.

Hueber, F.M. and Banks, H.P., 1967. Psilophyton princeps: the search for organic connection. Taxon, 16:81-85.

Kasper, A.E. and Andrews, H.N., 1972. Pertica, a new genus of Devonian plants from northern Maine. Am. J. Bot.. 59: 897-911.

Kidston, R. and Lang. W.H., 1917. On Old Red Sandstone plants showing structure, from the Rhynie Chert Bed, Aberdeenshire. Part I. Rhynia gwynne-vaughani Kidston and Lang. Trans. R. Soc. Edinburgh, 51: 761-784.

Li, Cheng-Sen, 1982. Hsuia robusta, a new land plant from the Lower Devonian of Yunnan, China. Acta Phytotaxon. Sin. 20: 331-342 (in Chinese, with an English abstract).

Stein, W.E., Wight, D.C. and Beck, C.B., 1982. Techniques for preparation of pyrite and limonite permineralizations. Rev Palaeobot. Palynol., 36: 185-194.

Stewart, W.N., 1983. Paleobotany and the Evolution of Plants Cambridge University Press, Cambridge, $405 \mathrm{pp}$. 